Prof. dr Emir ĆOROVIĆ *

Vanredni profesor

Departman za pravne nauke

Državnog univerziteta u Novom Pazaru
Originalni naučni rad

UDK: 343.261(497.11)

343.265.2(497.11)

343.846(497.11)

Primljeno: 19. mart 2021.

Prihvaćeno: 4. april 2021.

https://doi: 10.47152/rkkp.59.1.1

\title{
DOŽIVOTNI ZATVOR I USLOVNI OTPUST U KRIVIČNOM PRAVU SRBIJE: NEKA PITANJA I DILEME
}

Doživotni zatvor je uveden u krivično zakonodavstvo Srbije izmenama i dopunama Krivičnog zakonika iz 2019. godine. Njime je zamenjena dotadašnja kazna zatvora od 30 do 40 godina. Posebnu pažnju je privuklo zakonsko rešenje koje omogućava doživotni zatvor bez uslovnog otpusta za određena krivična dela. Takvo rěsenje se smatra protivnim članu 3 Evropske konvencije za zaštitu ljudskih prava i osnovnih sloboda. Ipak, zabrana uslovnog otpusta uvedena je u pravo Srbije još 2013. godine, donošenjem Zakona o posebnim merama za sprečavanje vršenja krivinih dela protiv polne slobode prema maloletnim licima. Međutim, tada se naučna $i$ stručna javnost nije u odgovarajućoj meri upustila u ocenu opravdanosti predmetne zabrane, koja sama po sebi otvara brojna pitanja. Zbog toga se prilikom razmatranja problematike doživotnog zatvora i uslovnog otpusta, odnosno njegove zabrane, mora voditi računa i o ranije uspostavljenom pravnom okviru, kao i o pitanjima koja jedna takva zabrana stvara, bez obzira da li se odnosi na doživotni ili ,,vremenski “ zatvor.

Ključne reči: doživotni zatvor, uslovni otpust, zabrana uslovnog otpusta.

e-mail: ecorovic@np.ac.rs 


\section{Uvod}

Izmenama i dopunama Krivičnog zakonika (KZ) iz maja meseca 2019. godine, ${ }^{1}$ koje su stupile na snagu 01 . decembra iste godine, u krivično zakonodavstvo Republike Srbije uvedena je kazna doživotnog zatvora (član 44a KZ). ${ }^{2}$ Iz Predloga zakona o izmenama i dopunama KZ iz 2019. godine, može se zaključiti da je ova kazna uvedena na inicijativu Fondacije „Tijana Jurić“, koja je podneta Narodnoj Skupštini Republike Srbije tokom 2017. godine, a koju je podržalo 158.460 građana Srbije. ${ }^{3}$ Otuda se navedene izmene kolokvijalno nazivaju Tijanin zakon. Međutim, i pre toga se razmišljalo o uvođenju doživotnog zatvora kod nas, tako da je ova kazna našla svoje mesto još u Nacrtu zakona o izmenama i dopunama KZ iz 2015. godine, ${ }^{4}$ ali ne i u sledujućem Predlogu izmena i dopuna KZ iz 2016. godine, ${ }^{5}$ koji je na posletku i usvojen, takođe 2016. godine. ${ }^{6}$ Doživotnim zatvorom zamenjena je ranija kazna zatvora od 30 do 40 godina, koja u srpskom KZ nominalno nije bila predviđena kao posebna kazna, već kao poseban raspon kazne zatvora za najteža krivična dela, odnosno najteže oblike teških krivičnih dela. U osnovi, smisao doživotnog zatvora je, kao i prijašnjeg zatvora od 30 do 40 godina, da bude(u) supstitut(i) smrtnoj kazni, tako da se njen (njihov) legitimitet crpi iz ,nepostojanja i nelegitimiteta druge kazne (smrtne kazne)“, što je, posmatrano teorijsko-koncepcijski, sporno (Ćorović, 2018: 196-197). Nezavisno od navedenog prigovora, moglo bi se tvrditi da je doživotni zatvor kao zamena za smrtnu kaznu ,čistije rešenje“ od zatvora u trajanju od 30 do 40 godina, jer simbolički u većoj meri odražava „princip srazmernosti i pravednosti kada je reč o najtežim slučajevima teških krivičnih dela“ (Stojanović, 2015: 6). Međutim, smrtna kazna je kod nas ukinuta 2002. godine, što je, u stvari, bio i najpogodniji momenat za uvođenje doživotnog zatvora, ali se tada smatralo da je kazna zatvora od 40 godina ,dovoljno duga da se društvo

\footnotetext{
1 Zakon o izmenama i dopunama KZ, Službeni glasnik RS, br. 35/2019.

2 Krivični zakonik, Službeni glasnik RS, br. 85/2005, 88/2005 - ispr., 107/2005 - ispr., 72/2009, 111/2009, 121/2012, 104/2013, 108/2014, 94/2016 i 35/2019.

3 Predlog zakona o izmenama i dopunama Krivičnog zakonika iz 2019., https://www.srbija.gov.rs/prikaz/358229, stranici pristupljeno 02.02.2021. Predlog izmena Krivičnog zakonika Fondacije „Tijana Jurić“", http://www.parlament.gov.rs/upload/archive/files/cir/pdf/akta_procedura/2017/Predlog\%20 izmene\%20Krivicnog\%20zakonika\%2003052017.pdf, stranici pristupljeno 05.02.2021.

4 Nacrt zakona o izmenama i dopunama Krivičnog zakonika, https://www.paragraf.rs/dnevne-vesti/080515/080515-vest13.html, stranici pristupljeno 19.03.2021.

5 Predlog zakona o izmenama i dopunama Krivičnog zakonika iz 2016., http://www.parlament. gov.rs/upload/archive/files/lat/pdf/predlozi_zakona/2769-16\%20-Lat..pdf , stranici pristupljeno 19.03.2021.).

6 Zakon o izmenama i dopunama KZ, Službeni glasnik RS, br. 94/2016.
} 
zaštiti od najtežih kriminalaca“" (Ignjatović, 2019: 124). Pogodan trenutak za uvođenje doživotnog zatvora mogla je biti i 2005. godina, u fazi donošenja važećeg KZ, ,jer je vremenska distanca od brisanja smrtne kazne iz sistema kazni bila manja“" (Kolarić, 2019: 25). Očigledno je da se u međuvremenu promenio stav zakonodavca u odnosu na iznalaženje adekvatne zamene za smrtnu kaznu, $\mathrm{s}$ tim da je na ovu promenu najmanje uticalo iskustvo u primeni prethodno postojećeg rešenja (zatvora od 30 do 40 godina), s obzirom da se u tom relativno kratkom vremenskom periodu nisu ni mogli sagledati njegovi efekti, tako da se stiče utisak da je na „raspoloženje“" zakonodavca u pravcu uvođenja doživotnog zatvora ,veći uticaj bio spolja, od javnosti, nego li iz oblasti nauke i struke“" (Radulović, 2020: 78).

Uvođenje doživotnog zatvora izazvalo je veliko interesovanje ne samo stručne, već i opšte javnosti. Za dobar deo stručne javnosti problematično je to što je isključena mogućnost primene uslovnog otpusta u slučajevima osude za određena krivična dela, a za koja je alternativno uz kaznu zatvora propisan i doživotni zatvor. To praktično znači da krivično pravo Republike Srbije poznaje doživotni zatvor bez mogućnosti uslovnog otpusta, što se smatra upitnim sa stanovišta člana 3 (zabrana mučenja $)^{7}$ Evropske konvencije za zaštitu ljudskih prava i osnovnih sloboda (Evropska konvencija). ${ }^{8}$ Međutim, zabrana uslovnog otpusta uvedena je u naše pravo pre izmena i dopuna KZ iz 2019., još 2013. godine, kada je donesen Zakon o posebnim merama za sprečavanje vršenja krivinih dela protiv polne slobode prema maloletnim licima, ${ }^{9}$ poznat kao Marijin zakon, u pogledu krivičnih dela koja su njime obuhvaćena (Jovašević, 2017: 59-60). ${ }^{10}$ Stručna javnost se, uglavnom, nije

7 Ovaj člana glasi: „Niko ne sme biti podvrgnut mučenju, ili nečovečnom ili ponižavajućem postupanju ili kažnjavanju“.

8 Zakon o ratifikaciji Evropske konvencije za zaštitu ljudskih prava i osnovnih sloboda, izmenjene u skladu sa Protokolom broj 11, Protokola uz Konvenciju za zaštitu ljudskih prava i osnovnih sloboda, Protokola broj 4 uz Konvenciju za zaštitu ljudskih prava i osnovnih sloboda kojim se obezbeđuju izvesna prava i slobode koji nisu uključeni u Konvenciju i Prvi Protokol uz nju, Protokola broj 6 uz Konvenciju za zaštitu ljudskih prava i osnovnih sloboda o ukidanju smrtne kazne, Protokola broj 7 uz Konvenciju za zaštitu ljudskih prava i osnovnih sloboda, Protokola broj 12 uz Konvenciju za zaštitu ljudskih prava i osnovnih sloboda i Protokola broj 13 uz Konvenciju za zaštitu ljudskih prava i osnovnih sloboda o ukidanju smrtne kazne u svim okolnostima, Službeni list SCG Međunarodni ugovori, br. 9/2003, 5/2005 i 7/2005 - ispr.; Službeni glasnik RS - Međunarodni ugovori, br. $12 / 2010$ i 10/2015.

9 Zakon o posebnim merama za sprečavanje vršenja krivičnih dela protiv polne slobode prema maloletnim licima, Službeni glasnik RS, br. 32/2013.

10 Član 3 Marijinog zakona glasi: „Ovaj zakon se primenjuje na učinioce koji su prema maloletnim licima izvršili sledeća krivična dela: 1) silovanje (član 178. st. 3. i 4. Krivičnog zakonika); 2) obljuba nad nemoćnim licem (član 179. st. 2. i 3. Krivičnog zakonika); 3) obljuba sa detetom (član 180. Krivičnog zakonika); 4) obljuba zloupotrebom položaja (član 181. Krivičnog zakonika); 5) nedozvoljene polne radnje (član 182. Krivičnog zakonika); 6) podvođenje i omogućavanje vršenja polnog 
obazirala na zabranu uslovnog otpusta ustanovljenu potonjim zakonom. ${ }^{11} \mathrm{Zbog}$ toga se pri razmatranju problematike doživotnog zatvora bez uslovnog otpusta mora voditi računa i o tome kakve sve posledice samo postojanje zabrane uslovnog otpusta, koja se „,apsolutno vezuje“ za određenu grupu krivičnih dela, može proizvesti na polju tumačenja i primene krivičnog prava. Jer, i da KZ nije predvideo zabranu uslovnog otpusta kod doživotnog zatvora, postojale bi odgovarajuće dileme u tom pravcu.

\section{Normativno uređenje doživotnog zatvora u krivičnom zakonodavstvu Srbije}

Doživotni zatvor predstavlja jednu od kazni koje poznaje srpski KZ, pored kazne zatvora, novčane kazne, rada u javnom interesu i oduzimanja vozačke dozvole (član 43). Može se izreći samo kao glavna kazna (član 44 stav 1 KZ). Postavlja se pitanje da li se neka druga kazna, kao sporedna, može izreći uz doživotni zatvor? Po logici stvari, u obzir bi mogla doći samo novčana kazna - tako je, na primer, zamislivo da se licu koje je izvršilo teško ubistvo iz koristoljublja uz doživotni zatvor, a na osnovu člana 48 stav $2 \mathrm{KZ}$, izrekne i novčana kazna (Vuković, 2021: 445-446). ${ }^{12}$ Ovakvi slučajevi bi mogli imati odgovarajuće kriminalno-političko opravdanje. Ali i pored toga, izricanje novčane kazne kao sporedne uz doživotni zatvor nije opravdano (Stojanović, 2019: 230). Naime, kod odredaba o odmeravanju jedinstvene kazne za krivična dela u sticaju je

odnosa (član 183. Krivičnog zakonika); 7) posredovanje u vršenju prostitucije (član 184. stav 2. Krivičnog zakonika); 8) prikazivanje, pribavljanje i posedovanje pornografskog materijala i iskorišćavanje maloletnog lica za pornografiju (član 185. Krivičnog zakonika); 9) navođenje maloletnog lica na prisustvovanje polnim radnjama (član 185a Krivičnog zakonika); 10) iskorišćavanje računarske mreže ili komunikacije drugim tehničkim sredstvima za izvršenje krivičnih dela protiv polne slobode prema maloletnom licu (član 185b Krivičnog zakonika)“.

11 Jedan deo teoretičara posvetio se kritici celokupnog koncepta Marijinog zakona (Ristivojević, 2013: 319-337). Nakon uvođenja zabrane uslovnog otpusta ovim zakonom, pojedini autori konstatuju: „Tako smo došli u situaciju da, protivno trendovima u modernim krivičnim naukama uvodimo zabranu uslovnog otpusta za učinioce određenih krivičnih dela, po uzoru na neke države u sastavu SAD-a“ (Ignjatović, 2016: 57-58). Uvođenje zabrane uslovnog otpusta Marijinim zakonom, za krivična dela za koja je, u to vreme, KZ dopuštao režim tzv. fakultativnog uslovnog otpusta, okarakterisano je „kao jedan od pokazatelja da se nije dovoljno vodilo računa da je Zakon o posebnim merama samo deo šire normativne celine, čiji bi delovi trebalo da budu međusobno usaglašeni“ (Miladinović-Stefanović, 2014: 571). Na kraju, pojedini autori eksplicitno navode da je donošenjem Marijinog zakona 2013. godine ,povučen pogrešan potez“ kada je osuđenim licima na kaznu zatvora koja potpadaju pod predmetni zakon ,ukinuto pravo na uslovni otpust“"(Ilić, G. 2019: 126.).

12 Predmetna odredba glasi: „Za krivična dela učinjena iz koristoljublja novčana kazna kao sporedna kazna može se izreći i kad nije propisana zakonom ili kad je zakonom propisano da će se učinilac kazniti kaznom zatvora ili novčanom kaznom, a sud kao glavnu kaznu izrekne kaznu zatvora“. 
propisano da će se, u slučaju da je za neko krivično delo u sticaju utvrđen doživotni zatvor, izreći samo ta kazna (član 60 stav 2 tačka $1 \mathrm{KZ}$ ), tj. kazna doživotnog zatvora (sistem apsorpcije). U tom smislu, ukoliko će se za sticaj (tj. više krivičnih dela) izreći samo doživotni zatvor, onda bi bilo „nelogično da drugačije važi i kada se odmerava kazna za samo jedno krivično delo“ (Vuković, 2021: 446). Pored ove argumentacije, može se reći i da odredba člana 48 stav 2 KZ govori o izricanju novčane kazne za krivična dela iz koristoljublja samo kada sud „kao glavnu kaznu izrekne kaznu zatvora“. Prema tome, ova odredba ne predviđa mogućnost izricanje novčane kazne uz doživotni zatvor.

Prema članu 44a stav $1 \mathrm{KZ}$ doživotni zatvor se može propisati: a) izuzetno, b) samo za najteža krivična dela i najteže oblike teških krivičnih dela i c) samo uz kaznu zatvora, što znači da se ne može propisati kao jedina kazna za odgovarajuće krivično delo. Iz analize posebnog dela KZ proizlazi da je doživotni zatvor propisan za sledeća krivična dela: teško ubistvo (član 114); najteži oblici silovanja (član 178 stav 4), ${ }^{13}$ obljube nad nemoćnim licem (član 179 stav 3), ${ }^{14}$ obljube nad detetom (član 180 stav 3$)^{15}$ i obljube zloupotrebom položaja (član 181 stav 5); ${ }^{16}$ ubistvo predstavnika najviših državnih organa (član 310); najteži oblici teškog dela protiv ustavnog uređenja i bezbednosti Srbije (član 321 st. 2 i 3); ${ }^{17}$ najteži oblik udruživanje radi vršenja krivičnih dela - samo za organizatora grupe ili organizovane kriminalne grupe (član 346 stav 5); ${ }^{18}$ genocid (član 370); zločin protiv čovečnosti (član 371); najteži oblici ratnih zločina protiv civilnog stanovništva (član 372 stav 3 ), ${ }^{19}$ ranjenika i bolesnika (član 373 stav 2), ${ }^{20}$ ratnih zarobljenika (član 374 stav 2) ${ }^{21}$ zatim upotrebe nedozvoljenih sredstava borbe (član 376 stav 2), ${ }^{22}$ protivpravnog ubijanja

13 Kvalifikatorna okolnost: smrt pasivnog subjekta ili je delo izvršeno prema detetu.

14 Kvalifikatorna okolnost: smrt pasivnog subjekta ili je delo izvršeno prema detetu.

15 Kvalifikatorna okolnost: smrt deteta.

16 Kvalifikatorna okolnost: smrt deteta.

17 Kvalifikatorna okolnost: da je pri vršenju taksativno nabrojanih krivičnih dela protiv ustavnog uređenja i bezbednosti Republike Srbije učinilac sa umišljajem lišio života jedno ili više lica (stav 2), odnosno da su određena taksativno navedena krivična dela iz ove grupe izvršena za vreme ratnog stanja, oružanog sukoba ili vanrednog stanja (stav 3).

18 Kvalifikatorna oklnost: da je reč o grupi ili organizovanoj kriminalnoj grupi koja ima za cilj vršenje krivičnih dela za koje se može izreći kazna zatvora od dvadeset godina ili doživotni zatvor.

19 Kvalifikatorna okolnost: da je naređeno da se za vreme rata, oružanog sukoba ili okupacije prema civilnom stanovništvu vrše ubistva ili izvršenje takvog dela.

20 Kvalifikatorna okolnost: da je naređeno da se za vreme rata, oružanog sukoba ili okupacije prema ranjenicima i bolesnicima vrše ubistva ili izvršenje takvog dela.

21 Kvalifikatorna okolnost: da je naređeno da se prema ratnim zarobljenicima vrše ubistva ili izvršenje takvog dela.

22 Kvalifikatorna okolnost: da je poginulo više lica. 
i ranjavanja neprijatelja (član 378 st. 3 i 4), ${ }^{23}$ agresivnog rata (član 386 stav 2), terorizma (član 391 stav 4$),{ }^{24}$ upotrebe smrtonosne naprave (član 391v stav 3 ), ${ }^{25}$ uništenja i oštećenja nuklearnog objekta (član $391 \mathrm{~g}$ stav 3$)^{26}$ i ugrožavanja lica pod međunarodnom zaštitom (član 392 stav 2). ${ }^{27}$

Od svih navedenih krivičnih dela za koje je propisan doživotni zatvor, u teoriji se spornim smatraju slučajevi najtežih oblika krivičnih dela silovanja, obljube nad nemoćnim licem, obljube nad detetom i obljube zloupotrebom položaja (Ilić, V., 2019: 157). Naime, kod ovih krivičnih dela je kao kvalifikatorna okolnosti, između ostalog, navedena i smrt pasivnog subjekta. Nije sporno da se u tim situacijama radi o krivičnom delu kvalifikovanom težom posledicom, što znači da se sama smrt pasivnog subjekta kao teža posledica pripisuje učiniočevom nehatu, dok su osnovna krivična dela iz kojih je ova posledica proizašla umišljajna. Time je, prema propisanim kaznama, izjednačeno teško ubistvo, koje je uvek umišljajno, sa najtežim slučajevima silovanja, obljube nad nemoćnim licem, obljube nad detetom i obljube zloupotrebom položaja iz kojih se proistekla smrt može pripisati učiniočevom nehatu (Škulić, 2019: 64; Ilić, V., 2019: 158). Štaviše, u tome se vide i „neki elementi objektivne odgovornosti““ (Škulić, 2019: 64). Iako je ovaj prigovor prilično osnovan, odnosno postojeće zakonsko rešenje je kriminalno-politički dubiozno, ono postoji u još nekim pravima, kao što je slučaj sa nemačkim KZ (Ilić, V., 2019: 158; Vuković, 2021: 445). ${ }^{28}$

Doživotni zatvor ne može se izreći licu koje u vreme izvršenja krivičnog dela nije navršilo dvadeset jednu godinu života (član 44a stav $2 \mathrm{KZ}$ ). Za izricanje ove kazne relevantne su godine starosti učinioca u vreme izvršenja krivičnog dela, a ne u vreme suđenja. Povodom ovog ograničenja, regulativa iz

23 Kvalifikatorna okolnost: da je ubistvo izvršeno na svirep način ili iz koristoljublja ili da je ubijeno više lica (stav 3), odnosno da je učinilac kršeći pravila međunarodnog prava za vreme rata ili oružanog sukoba naredio da u borbi ne sme biti preživelih pripadnika neprijatelja ili vođenje borbe protiv neprijatelja na toj osnovi (stav 4).

24 Kvalifikatorna okolnost: da je pri izvršenju neke od terorističkih aktivnosti učinilac sa umišljajem lišio života jedno ili više lica.

25 Kvalifikatorna okolnost: da je učinilac pri izvršenju dela sa umišljajem lišio života jedno ili više lica.

26 Kvalifikatorna okolnost: da je učinilac pri izvršenju dela sa umišljajem lišio života jedno ili više lica.

27 Kvalifikatorna okolnost: da je pri vršenju dela nastupila smrt jednog ili više lica.

28 Odredba $§ 176 \mathrm{~b}$ nosi naziv „Sexueller Mißbrauch von Kindern mit Todesfolge“/ „Seksualna zloupotreba dece sa smrtnom posledicom“. Odredba glasi: „Verursacht der Täter durch den sexuellen Mißbrauch (\$\$ 176 und 176a) wenigstens leichtfertig den Tod des Kindes, so ist die Strafe lebenslange Freiheitsstrafe oder Freiheitsstrafe nicht unter zehn Jahren“/ „Ako izvršilac seksualne zloupotrebe ( $\S 176$ i 176a) bar lakomisleno uzrokuje smrt deteta, kazniće se doživotnim zatvorom ili od najmanje deset godina“. Lakomislenost (Leichtfertigkeit) predstavlja veći stepen svesnog i nesvesnog nehata koji odgovara gruboj nepažnji (nehatu) iz građanskog prava (Lackner, Kühl, 2011: 131). Odredba $\S 176 \mathrm{~b}$ nemačkog KZ predstavlja krivično delo kvalifikovano težom posledicom erfolgsqualifizierte Delikt (Lackner, Kühl, 2011: 822). 
domaćeg krivičnog kodeksa ,ide mnogo dalje od međunarodnih dokumenata, prakse Evropskog suda za ljudska prava i drugih evropskih država“" (Kolarić, 2015: 655). Tako je, na primer, u članu 37 stav 1 tačka a) Konvencije o pravima deteta ${ }^{29}$ predviđeno: „Ni smrtna kazna, ni doživotni zatvor, bez mogućnosti oslobađanja, neće biti dosuđeni za dela koja izvrše osobe mlađe od 18 godina“. Prema tome, najznačajniji dokument koji se odnosi na prava deteta (tj. lica mlađih od 18 godina u smislu ove Konvencije) ne isključuje doživotno kažnjavanje lica mlađih od 18 godina, pod uslovom da postoji „mogućnost oslobađanja“. U nekoliko odluka se Evropski sud za ljudska prava (ESLJP) bavio problematikom doživotnog zatvora prema maloletnicima: u predmetu Weeks protiv Velike Britanije, predstavka broj 9782/82, Sud je našao da je doživotni zatvor izrečen sedamanaestogodišnjaku prihvatljiv ,samo zato što on ima realne izglede da bude oslobođen i zahtevao je da dodatne proceduralne garancije budu date za razmatranje njegovog oslobađanja“ (Kolarić, 2015: 654); u predmetu V v. protiv Velike Britanije, predstavka broj 24888/94, naglašen je ,značaj predviđanja jasnog i relativno kratkog minimalnog perioda nakon koga se oslobađanje mora razmotriti, posebno u slučajevima gde je prestupnik bio veoma mlad u vreme izvršenja dela“" (Kolarić, 2015: 654). Prema istraživanju CRIN-a (Child Rights International Network) doživotni zatvor se može izreći maloletnicima u pravima sledećih evropskih država: Kipra, Francuske i Velike Britanije (CRIN, 2015: 36).

U stavu 3 člana 44a KZ predviđena su još dva ograničenja za izricanje ove kazne. Naime, doživotni zatvor se ne može izreći u slučajevima kada zakon predviđa da se kazna može ublažiti (član 56 stav 1 tačka $1 \mathrm{KZ}$ ) ili kada postoji neki od osnova za oslobođenje od kazne. U tom smislu, postojanje nekih od zakonskih osnova ublažavanja kazne (prekoračenje nužne odbrane ili krajnje nužde, bitno smanjena uračunljivost, kompulzivna sila i pretnja, otklonjiva pravna zabluda, pokušaj, pomaganje) ili oslobođenja od kazne (prekoračenje granica nužne odbrane usled jake razdraženosti ili prepasti izazvane napadom, krajnja nužda pod naročito olakšavajućim okolnostima, nepodoban pokušaj, dobrovoljni odustanak, sprečavanje krivičnog dela od strane saučesnika, kao i odgovarajući zakonski osnovi iz posebnog dela koji su predviđene za određene inkriminacije) isključuju mogućnost izricanja doživotnog zatvora. Može se postaviti pitanje da li se navedeno ograničenje odnosi i na ona krivična dela za koja je zaprećen doživotni zatvor, a kod kojih je ublažavanje isključeno po posebnoj zakonskoj odredbi (misli se na teško ubistvo iz člana 114 i krivična dela iz čl. 178, 179 i 180, a prema članu 57 stav 2 KZ). Ispravno je uzeti da se odredbe člana 44a stav 3 i člana 57 stav $2 \mathrm{KZ}$,nečelno ne potiru“,

29 Zakon o ratifikaciji Konvencije Ujedinjenih nacija o pravima deteta, Službeni list SFRJ - Međunarodni ugovori, br. 15/90, Službeni list SRJ - Međunarodni ugovori, br. 4/96 i 2/97. 
tako da se u navedenim situacijama doživotni zatvor ne bi mogao izreći (Vuković, 2021: 446). Tako na primer, za pokušaj silovanja deteta (član 178 stav $4 \mathrm{KZ}$ ) kazna se ne bi mogla ublažiti primenom člana 57 stav $2 \mathrm{KZ}$, ali se učiniocu ne bi mogla izreći kazna doživotnog zatvora. ${ }^{30}$

Opisana ograničenja kriminalno-politički svakako su opravdana, ali otvaraju niz praktičnih problema. Naime, svojevremeno je, povodom Nacrta izmena i dopuna KZ iz 2015. godine, na sednici Krivičnog odeljenja Vrhovnog kasacionog suda, održanoj dana 09.06.2015. godine, iznet jedinstven predlog da se kazna doživotnog zatvora ne uvodi u naš sistem kazni (Dragičević-Dičić, 2015: 15), a tim povodom su iskazana i određena, veoma bitna zapažanja, koja zaslužuju da budu citirana: „u praksi (je) bilo slučajeva da neko ubije jedno lice, pri tome rani više lica, što se u prihvaćenoj sudskoj praksi kvalifikuje kao pokušaj teškog ubistva, odnosno teškog ubistva iz člana 114. tačka 11, koja se odnosi na umišljajno lišenje života više lica. Po odredbi Nacrta zakonika za ovakvo krivično delo, iako se radi o krivičnom delu teškog ubistva ne bi se mogla izreći kazna doživotnog zatvora, već maksimalno 20 godina zatvora. Posebno će biti značajni krivični postupci za teška ubistva, izvršena na svirep ili podmukao način, od kojih neka već zaokupljuju pažnju javnosti, gde je utvrđena bitno smanjena uračunljivost izvršioca. U tim slučajevima kazna doživotnog zatvora se ne može izreći. Data ograničenja će u svakom slučaju umanjiti željeni efekat uvođenja kazne doživotnog zatvora“" (Dragičević-Dičić, 2015: 14-15).

Pored navedenih problema sa kojima će se sudovi zasigurno suočavati u praksi, mogu se identifikovati i određeni problemi koji se svode na relaciju doživotni zatvor - mere bezbednosti. Naime, učiniocu koji je tempore criminis postupao u stanju bitno smanjene uračunljivosti, a pri tome je kod njega utvrđeno postojanje ozbiljne opasnosti ponavljanje težeg krivičnog dela, kao i potreba da se, radi otklanjanja ove opasnosti, leči u zdravstvenoj ustanovi, sud ne bi mogao izreći doživotni zatvor (ukoliko je učinio krivično delo sa tako zaprećenom kaznom) i uz tu kaznu meru bezbednosti obaveznog psihijatrijskog lečenja i čuvanja u zdravstvenoj ustanovi iz člana $81 \mathrm{KZ}$. Ovo iz razloga što bitno smanjena uračunljivost predstavlja zakonski osnov za ublažavanje kazne, čime je u smislu prethodno rečenog isključena mogućnost primene doživotnog zatvora. Iz ovoga proizlazi nespojivost doživotnog zatvora i navedene mere bezbednosti. Mogla bi se zastupati teza da za kumulativnim izricanjem ove dve krivične sankcije nema potrebe, jer je trajanje obaveznog psihijatrijskog lečenja i čuvanja u zdravstvenoj ustanovi regulisano po sistemu apsolutno neodređenog trajanja, tj. sud će obustaviti

30 Ipak, sporno je u teoriji da li se odredba člana 57 stav $2 \mathrm{KZ}$ odnosi na tzv. zakonsko ublažavanje kazne (o tome, Ćorović, 2020: 167-169; Vuković, 2021: 490-491). 
ovu meru kada utvrdi da je prestala potreba za lečenjem i čuvanjem učinioca u zdravstvenoj ustanovi, s tim da ona, ukoliko je izrečena uz kaznu zatvora, može trajati i duže od ove kazne. To znači da predmetna mera bezbednosti faktički može trajati doživotno, ukoliko lečenje ne daje rezultate koji opravdavaju njenu obustavu (o ovome, Stojanović, 2015: 7-8).

Kada se razmatra ova problematika ne treba smetnuti sa uma da je jedan od bioloških osnova neuračunljivosti i bitno smanjene uračinljivosti ,druga teža duševna poremećenost" u koju spadaju, između ostalog, poremećaji nagona, uključujući i seksualne nagone (Delić, 2009: 128, 135-137). Imajući u vidu da je doživotni zatvor naročito ,interesantan“ kod odgovarajućih krivičnih dela protiv polne slobode, nije teško pretpostaviti koncept i pravac odbrane u krivičnim postupcima za navedena krivična dela, s ciljem izbegavanja izricanja najstrožije kazne. U tim situacijama učiniocu bi više odgovaralo da bude osuđen na vremenski zatvor i meru bezbednosti obaveznog psihijatrijskog lečenja i čuvanja u zdravstvenoj ustanovi, jer bi se protekom izrečene kazne zatvora, koja bi u tim slučajevima mogla maksimalno iznositi 20 godina, mogao naći na slobodi ukoliko se proceni da ne postoji potreba daljeg lečenja (vreme provedeno u zdravstvenoj ustanovi uračunava se u izrečenu kaznu zatvora prema članu 81 stav $5 \mathrm{KZ}$ ).

Može biti upitna i mogućnost izricanja mera bezbednosti obaveznog lečenja narkomana i obaveznog lečenja alkoholičara uz doživotni zatvor. Član 80 stav $4 \mathrm{KZ}$ dopušta kumulativno izricanje ovih sankcije, jer je u njemu propisano da se predmetne mere mogu izreći, između ostalog, ako je učiniocu izrečena kazna (u koje spada i doživotni zatvor). Međutim, pitanje je koliko bi one mogle trajati uz ovu kaznu? Naime, u čl. 83 i 84 KZ koji normiraju mere bezbednosti obaveznog lečenja narkomana i obaveznog lečenja alkoholičara nije predviđeno njihovo trajanje uz doživotni zatvor, već samo uz zatvor, novčanu kaznu, uslovnu osudu, sudsku opomenu i oslobođenje od kazne. S druge strane, izricanje ovih mera bezbednosti je obavezno (,sud će“) ukoliko su ispunjeni zakonom postavljeni uslovi. Izlaz iz ove situacije bi se mogao iznaći u tumačenju da izricanje mera iz čl. 83 i $84 \mathrm{KZ}$ ipak nije dopušteno uz doživotni zatvor, jer odredbu člana 80 stav $4 \mathrm{KZ}$, koja dopušta izricanje obaveznog lečenja narkomana i obaveznog lečenja alkoholičara uz „kaznu“, treba razumeti kao lex generalis, dok bi odredbe čl. 83 i $84 \mathrm{KZ}$ predstavljale lex specialis, a po njima opisana mogućnost nije predviđena. U svakom slučaju, osuđenik kome je izrečen doživotni zatvor, a pri tome je zavisnik od opojnih droga odnosno alkohola, ima prava na lečenje od bolesti zavisnosti na osnovu odredaba o zdravstvenoj zaštiti osuđenika, prema članu 114 Zakona o izvršenju krivičnih sankcija (ZIKS). ${ }^{31}$

31 Zakon o izvršenju krivičnih sankcija, Službeni glasnik RS, br. 55/2014 i 35/2019. 
Nesporno je da se uz doživotni zatvor može izreći mera bezbednosti oduzimanja predmeta, jer to proizlazi iz opšte odredbe člana 80 stav $4 \mathrm{KZ}$, s tim da odredba člana $87 \mathrm{KZ}$, koja bliže uređuje ovu meru, ne sadrži nikakva ograničenja u tom pogledu. Kada je reč o ostalim merama bezbednosti, naročito onim prohibitivnog karaktera (koje se sastoje iz odgovarajućih zabrana), pitanje mogućnosti njihovog izricanja uz doživotni zatvor čini se suvišnim, jer učinilac izdržava kaznu „doživotno“. Međutim, u članu 80 stav $7 \mathrm{KZ}$ je propisano da će se za krivična dela u sticaju izreći mera bezbednosti ako je utvrđena makar za jedno od tih krivičnih dela. Pri tome, nekada je izricanje neke od ovih mera bezbednosti obavezno. Na primer, izricanje zabrane upravljanja motornim vozilom za teško delo protiv bezbednosti javnog saobraćaja (član 297 KZ). Zamisliva je situacija da je neko lice u realnom sticaju izvršilo navedeno delo i, na primer, teško ubistvo; ukoliko mu je za teško ubistvo utvrđen doživotni zatvor, isti će u jedinstvenoj kazni apsorbovati kaznu za teško delo protiv bezbednosti javnog saobraćaja, ali i dalje ostaje „obavezna“ mera bezbednosti zabrane upravljanja motornim vozilom, koja se u smislu pomenutih odredaba mora izreći uz doživotni zatvor. Ovo može imati nekog smisla usled činjenice da osuđenik može ranije „,izaći“ sa izdržavanja doživotnog zatvora (po osnovu uslovnog otpusta, amnestije ili pomilovanje, odnosno naknadnog revidiranja pravnosnažne presude po osnovu vanrednog pravnog leka, kada mu se doživotni zatvor preinači u vremenski). Ipak, bilo bi korisno da ova pitanja budu predmet neke zakonodavčeve buduće novele, odnosno potrebno je bliže urediti odnos između doživotnog zatvora i mera bezbednosti.

U članu $108 \mathrm{KZ}$ je predviđeno da krivično gonjenje i izvršenje kazne za krivična dela za koja je propisana kazna doživotnog zatvora ne zastareva. Navedena odredba, prema tome, nezastarivost krivičnog gonjenja i izvršenja kazne vezuje za propisanu kaznu doživotnog zatvora. U tom smislu, ne samo da ne zastareva izvršenje izrečene kazna doživotnog zatvora, već ni izvršenje vremenske kazne zatvora koja je izrečena za krivično delo za koje je propisan doživotni zatvor (na primer, za teško ubistvo nije iskorišćena mogućnost izricanja doživotnog zatvora, već je izrečen zatvor od 15 godina). Postavlja se pitanje ustavnosti predmetne odredbe o nezastarivosti krivičnog gonjenja i izvršenja kazne za krivična dela za koja je propisan doživotni zatvor (Vuković, 2021: 446), jer je u članu 34 stav 6 Ustava propisano da krivično gonjenje i izvršenje kazne ne zastareva jedino za ratni zločin, genocid i zločin protiv čovečnosti, kao i da se, na osnovu člana 20 stav 1 lex superior-a, ljudska prava zajemčena Ustavom mogu zakonom ograničiti samo ukoliko ograničenje dopušta Ustav. 


\section{Doživotni zatvor i uslovni otpust - zabrana uslovnog otpusta u krivičnom zakonodavstvu Srbije}

Kada je reč o uslovnom otpustu kod doživotnog zatvora, KZ je predvideo dva režima. Načelno, osuđeni kome je izrečen doživotni zatvor stiče pravo na uslovni otpust nakon izdržanih 27 godina zatvora (član 46 stav 2 alineja prava). $\mathrm{U}$ ovom slučaju, reč je o fakultativnom uslovnom otpustu, ${ }^{32}$ jer je predviđeno da „sud može“ uslovno otpustiti osuđenog na kaznu doživotnog zatvora pod uslovima koji su predviđeni u članu 46 stav $1 \mathrm{KZ}$. Do uslovnog otpuštanja u ovoj situaciji može doći ako se osuđeni $u$ toku izdržavanja kazne tako popravio da se može sa osnovom očekivati da će se na slobodi dobro vladati, a naročito da do isteka vremena trajanja uslovnog otpusta, koji prema članu 47 stav $7 \mathrm{KZ}$ kod doživotnog zatvora traje petnaest godina od dana uslovnog otpuštanja, ne učini novo krivično delo. ${ }^{33}$ Pri oceni da li će osuđenog uslovno otpustiti sud uzima u obzir: 1) njegovo vladanje za vreme izdržavanja kazne, 2) izvršavanje radnih obaveza, s obzirom na njegovu radnu sposobnost, 3) druge okolnosti koje ukazuju da osuđeni dok traje uslovni otpust neće izvršiti novo krivično delo.

Drugi režim se odnosi na zabranu uslovnog otpusta u slučaju osude za sledeća krivična dela (član 46 stav $5 \mathrm{KZ}$ ): teško ubistvo (član 114 stav 1 tačka 9), ${ }^{34}$ silovanje (član 178 stav 4), obljuba nad nemoćnim licem (179 stav 3), obljuba sa detetom (član 180 stav 3) i obljuba zloupotrebom položaja (član 181 stav 5). U ovom slučaju zabrana nije vezana za propisanu ili izrečenu kaznu, već za krivično delo koje je predmet osude, tj. ona se odnosi „, na bilo ko-

32 Pored fakultativnog uslovnog otpusta u našem pravu postoji i obavezni uslovni otpust, koji je regulisan u članu 46 stav $1 \mathrm{KZ}$. U stvari, obavezni uslovni otpust bi trebalo da bude pravilo. Da je reč o obaveznom uslovnom otpustu proizlazi iz same dikcije člana 46 stav $1 \mathrm{KZ}$, u kojem stoji formulacija ,sud će uslovno otpustiti“, s tim da ova formulacija ne znači i automatizam u otpuštanju, jer osuđeni mora ispunjavati zakonom predviđene uslove. Kod fakultativnog uslovnog otpusta iz člana 46 stav 2 KZ, koji se odnosi samo na određene kategorije osuđenika, stoji formulacija „,sud može uslovno otpustiti“ (više Ćorović, 2015: 102-105), što znači da su sudu data šira diskreciona ovlašćenja nego u prvom slučaju. U vezi sa fakultativnim uslovnim otpustom se navodi da je zakonodavac time ,„želeo da pošalje jasnu poruku da izvršioci pojedinih kategorija izuzetno teških krivičnih dela ne mogu "preuranjeno" dobiti drugu šansu pod istim uslovima kao kada je reč o ostalim osuđenicima“. Međutim, dodaje se i sledeće: „bez propisivanja preciznih kriterijuma na osnovu kojih bi sud trebalo da napravi razliku u oceni postignutog napretka za osuđenike iz obe pomenute kategorije, čini se da odredba stava 2. nema naročitog značaja na polju primene, osim što otvara prostor za arbitrernost“" (Kolaković-Bojović, 2017: 146-147).

33 U odredbi člana 46 stav $1 \mathrm{KZ}$ stoji formulacija „,...naročito da do isteka vremena za koje je izrečena kazna ne učini novo krivično delo“. Kada je reč o doživotnom zatvoru navedena formulacija nema smisla, jer sam uslovni otpust ne traje doživotno, već 15 godina od dana kada je osuđeni uslovno otpušten.

34 Radi se o lišenju života deteta ili bremenite žene. 
ju kaznu zatvora koja bude izrečena učiniocu nekog od navedenih krivičnih dela“ (Ilić, G., 2019: 126). Međutim, za sva nabrojana krivična dela je, kako je navedeno, propisan doživotni zatvor. To znači da osuđeni kojem je za neko od navedenih krivičnih dela izrečen doživotni zatvor, potpada pod režim zabrane uslovnog otpusta.

Pre nego što se razmtri problematika na relaciji doživotni zatvor - uslovni otpust, potrebno je malo bliže ukazati na samu zabranu uslovnog otpusta u našem pravu. U srpskom pravu mogu se razlikovati relativna i apsolutna zabrana uslovnog otpusta. Naime, izmenama i dopunama KZ iz 2012., odnosno 2016. godine, uvedeno je pravilo da se ne može se uslovno otpustiti osuđeni koji je tokom izdržavanja kazne dva puta kažnjavan za teže disciplinske prestupe i kome su oduzete dodeljene pogodnosti. ${ }^{35}$ Disciplinske mere izrečene za teže disciplinske prestupe brišu se iz evidencije disciplinskih mera u roku od tri godine od dana njihovog izricanja (o tome, Drakić, Milić, 2019a: 407-408), pod uslovom da osuđenom u tom periodu ne bude izrečena nova disciplinska mera (član 175 ZIKS). Brisanjem disciplinske mere, osuđeno lice, ,izlazi“ iz režima zabrane uslovnog otpusta. Zbog toga je ova zabrana relativna (o tome, Milić, 2020: 371). Apsolutna zabrana uslovnog otpusta uvedena je pomenutim Marijinim zakonom iz 2013. godine. Prema članu 5 stav 2 ovog Zakona lica osuđena za krivična dela koja potpadaju pod njegov režim ne mogu se uslovno otpustiti. U ovom slučaju se zabrana vezuje za vrstu krivičnog dela na koju je učinilac osuđen. Zabrana je apsolutna, jer ova lica nikako ne mogu ,izaći“ iz režima zabrane, tako da ona moraju u celosti izdržati kaznu (Milić, 2020: 371). Izmenama i dopunama KZ iz 2019. godine, a povodom pomenute odredbe člana 46 stav 5 KZ, samo je proširena apsolutna zabrana ublažavanja kazne. Preciznije rečeno, sva krivična dela koja su pomenuta u članu 46 stav $5 \mathrm{KZ}$, osim teškog ubistva iz člana 114 stav 1 tačka $9 \mathrm{KZ}$, već su obuhvaćena Marijinim zakonom. Prema tome, i bez odredbe člana 46 stav $5 \mathrm{KZ}$ osuđenici za krivična dela iz člana 178 stav 4, člana 179 stav 3, člana 180 stav 3 i člana 181 stav 5 KZ lišeni su mogućnosti uslovnog otusta na osnovu člana 5 stav 2 Marijinog zakona. Novele KZ iz 2019. godine su samo omogućile, usled uvođenja doživotnog zatvora, da apsolutna zabrana važi doživotno.

35 Pre toga, izmenama i dopunama KZ iz 2009. godine, bila je uvedena zabrana uslovnog otpuštanja za lice koje pokušalo da pobegne ili je pobeglo iz zavoda za izvršenje kazne zatvora u toku izdržavanja kazne. Izmenama i dopunama KZ iz 2012. godine ova odredba je promenjena, tako da se zabrana uslovnog otpusta odnosila na osuđenog koji je tokom izdržavanja kazne dva puta kažnjavan za disciplinske prestupe i kome su oduzete dodeljene pogodnosti. Izmenama i dopunama KZ iz 2016. precizirano je da se disciplinsko kažnjavanje koje isključuje mogućnost uslovnog otpusta odnosi na teže disciplinske prestupe. 
Apsolutna zabrana uslovnog otpusta sama po sebi može stvoriti odgovarajuće praktične probleme u slučaju kada je neko lice osuđeno za više krivičnih dela u sticaju, od kojih jedno povlači zabranu uslovnog otpusta, a druga ne povlače ovu zabranu. Pitanje je, pod koji režim spada izrečena jedinstvena kazna? Na primer, izvršeno je krivično delo silovanja maloletnika iz član 178 stav $3 \mathrm{KZ}$ (delo potpada pod Marijin zakon), za koje je utvrđena kazna zatvora od 7 godina, i krivično delo ubistva iz člana $113 \mathrm{KZ}$ (dozvoljen je uslovni otpust), za koje je utvrđena kazna zatvora od 12 godina, pa je izrečena jedinstvena kazna od 18 godina i 6 meseci. Da li u ovom slučaju osuđeni ima pravo na uslovni otpust? U ovom primeru je, čak, utvrđena veća kazna za krivično delo za koje je dopušten uslovni otpust, od krivičnog dela za koje je isključena njegova primena. Slično pitanje bi se moglo javiti i ukoliko su učiniocu za sticaj dva krivična dela, od kojih je za jedno dopušten uslovni otpust (teško ubistvo iz člana 114 stav 1 tačka $1 \mathrm{KZ}$ ), a za jedno nije (član 178 stav $4 \mathrm{KZ}$ ), utvrđene dve kazne doživotnog zatvora, pa mu se primenom odredaba o odmeravanju kazne za sticaj, po sistemu apsorpcije, izrekne jedinstvena kazna doživotog zatvora. Da li u ovom slučaju jedinstvena doživotna kazna podleže uslovnom otpustu ili ne? Za razliku od prethodnog primera, gde je zaista teško dati logičan i pravno valjan odgovor na postavljeno pitanje, u ovoj drugoj situaciji bi se, ipak, „,našao izlaz iz problema“. Naime, ako je za dva krivična dela utvrđen doživotni zatvor, od kojih za jedno delo važi zabrana uslovnog otpusta, onda će zabrana važiti i za jedinstvenu kaznu doživotnog zatvora, po principu argumentum a fortiori - minore ad maius. Međutim, ovim nije rešen problem ukoliko bi, u ovom poslednjem primeru, učiniocu za teško ubistvo iz člana 114 stav 1 tačka $1 \mathrm{KZ}$ bila utvrđena kazna doživotnog zatvora (gde je dopušten uslovni otpust), a za delo iz člana 178 stav $4 \mathrm{KZ}$ (gde važi zabrana uslovnog otpusta), vremenska kazna zatvora. Jedinstvena kazna bi i u ovom slučaju bila doživotni zatvor, ali se postavlja pitanje da li je dopušten uslovni otpust? Ili, zamislimo situaciju da je učinilac ubio dva lica, od kojih je jedno bremenita žena ili dete, pa je tim povodom osuđeno na doživotni zatvor. Da li u ovom slučaju osuđeni ima pravo na uslovni otpust, jer će se njegove radnje kvalifikovati kao teško ubistvo više lica iz člana 114 stav 1 tačka $11 \mathrm{KZ}$, za koje nije predviđena zabrana uslovnog otpusta, ali je, s druge strane, nesporno da ono u sebi sadrži krivično delo iz člana 114 stav 1 tačka $9 \mathrm{KZ}$, za koje je predmetna zabrana predviđena.

Postojanje doživotnog zatvora bez mogućnosti uslovnog otpusta protivno je članu 3 Evropske konvencije za zaštitut ljudskih prava i osnovnih sloboda (detaljno, Turanjanin, 2021: 4-9). Za ovu prolematiku je naročito od značaja presuda ESLJP u predmetu Vinter $i$ drugi protiv Ujedinjenog Kraljevstva 
(predstavke br. 66069/09, 130/10 i 3896/10), ${ }^{36}$ u kojem je postavljen zahtev za postojanjem mehanizma za preispitivanje doživotnog zatvora nakon 25 godina ( $\S \S 119-122)$. U ovoj odluci je naglašeno da tamo gde domaće pravo ne predviđa nikakav mehanizam ili mogućnost preispitivanja doživotnog zatvora, inkompatibilitet sa članom 3 nastaje još u trenutku izricanja doživotnog zatvora, a ne u kasnijim fazama izdržavanja kazne (poslednja rečenica $\S 122$ ). Navedeno je i da se u kontekstu doživotnog zatvora član 3 mora tumačiti kao zahtev za „smanjivošću“ kazne (,,as requiring reducibility of the sentence"), u smislu revizije koja domaćim vlastima omogućava da razmotre da li su promene kod osuđenika na doživotni zatvor značajne, kao i da je napredak u rehabilitaciji postignut upravo tokom izdržavanja kazne, čime se nastavak lišenja slobode više ne može pravdati na legitimnim penološkim osnovama (§ 119). U osnovi ESLJP, a povodom člana 3 Evropske konvencije, postavlja zahtev da doživotni zatvor bude de iure i de facto podložan smanjenju (redukovanju), odnosno da osuđenik ima pravo da zahteva otpuštanje sa ove kazne, što ne znači da će se njegovom zahtevu obavezno udovoljiti, tako da se njegov zahtev može odbiti uz obrazloženje da je osuđenik i dalje opasan po društvo, kako je istaknuto u presudi Laszlo Magyar protiv Mađarske (predstavka br. 73593/10 - §49). ${ }^{37}$ U potonjoj presudi je rečeno i da će, ukoliko domaće pravo daje mogućnost preispitivanja doživotnog zatvora u pogledu njegove zamene, smanjenja, ograničavanja ili uslovnog otpuštanja osuđenika, biti zadovoljeni uslovi iz člana 3 Evropske konvencije ( $\$ 50 \mathrm{uz}$ pozivanje na predmet Kafkaris). Ukoliko domaće pravo ne predviđa mogućnost takvog preispitivanja, doživotni zatvor neće biti u skladu sa standardima člana 3 Konvencije ( $(50)$. U ovom predmetu ( $\S 54-59)$, kao i u predmetu Öclan protiv Turske (predstavka 24069/03, 197/04, 6201/06 i 10464/07 §§ 201-207) ${ }^{38}$ navedeno je da mogućnosti davanja pomilovanja i amnestije ne ukazuju na „smanjivost“ doživotnog zatvora, pa je u tim slučajevima, tj. gde su samo predviđeni ovi mehanizmi prema osuđeniku na doživotni zatvor, povređen član 3 Evropske konvencije.

36 Vinter and Others v. The United Kingdom, (Applications nos. 66069/09, 130/10 and 3896/10), https://hudoc.echr.coe.int/eng\#\{\%22itemid\%22:[\%22001-122664\%22]\}, stranici pristupljeno 07.03.2021.

37 Laszlo Magyar v. Hungary, (Application no. 73593/10), https://hudoc.echr.coe.int/eng\#\{\%22itemid\%22:[\%22001-144109\%22]\}, stranici pristupljeno 07.03.2021.

38 Öclan v. Turkey, (Aplications nos. 24069/03, 197/04, 6201/06 and 10464/07). https:// hudoc.echr.coe.int/eng\#\{\%22 languageisocode \%22:[\%22 ENG\%22],\%22 appno\%22:[\%2224069/03\%22,\%22197/04\%22,\%226201/06\%22,\%2210464/07\%22],\%22documentcollectionid2\%22:[\%22CHAMBER\%22],\%22itemid\%22:[\%22001-142087\%22]\}, stranici pristupljeno 07.03.2021. 
U srpskom pravu osuđenici na doživotni zatvor bez uslovnog otpusta mogu biti obuhvaćeni aktima amnestije i pomilovanja, što znači da i u ovom slučaju postoje zakonske mogućnosti da se takvi osuđenici ipak nađu na slobodi. Međutim, u smislu prethodno rečenog, radi se o aktima političke milosti koji ne predstavljaju garanciju „smanjivosti“ doživotnog zatvora, pa ovi instituti ne odražavaju zahteve iz člana 3 Evropske konvencije u skladu sa tumačenjima ESLJP suda (o tome da pomilovanje kod nas ne zadovoljava ni de facto ni de iure uslove smanjivosti videti Ilić, G., 2019: 139). Nadalje, osuđenici na doživotni zatvor (bez obzira da li imaju pravo na uslovni otpust ili ne) ne mogu biti prevremeno otpušteni u smislu čl. 184 i 184a ZIKS, jer se ovi instituti vezuju za vremenske kazne zatvora. ${ }^{39}$

Prema tome, doživotni zatvor sam po sebi nije protivan članu 3 Evropske konvencije, ali jeste u slučaju da nacionalno zakonodavstvo ne predviđa odgovarajući mehanizam koji daje mogućnost da se ova kazna preispita nakon izvesnog vremena. Inače, problematikom doživotnog zatvora bavili su se i ustavni sudovi Italije i Nemčke još 70-tih godina prošlog veka. U Italiji se postavilo pitanje kompatibilnosti doživotnog zatvora sa članom 27 stav 3 njenog Ustava, koji u navedenoj odredbi propisuje rehabilitacionu funkciju osude. U svojoj odluci br. 264 iz 1974. godine Ustavni sud Italije je odbacio ovu sumnju navodeći da ,svrha kazne nije samo da rehabilituje učinioca, nego i da zaštiti društvo i neutrališe opasnost koju poseduju određeni učinioci za neodređeni period“" (Manna, Infante, 2000: 40). Međutim, u pravu Italije osuđenici na doživotni zatvor imaju prava na uslovni otpust nakon izdržanih 26 godina (Manna, Infante, 2000: 41, 52). Savezni ustavni sud Nemačke je u svojoj odluci iz 1977. godine takođe stao na stanovištu da doživotni zatvor sam po sebi nije protivan ustavu sve dok se osuđenom „ostavlja “'konkretna i u osnovi realna mogućnost" da u jednom trenutku ponovo postane slobodan građanin“ (Đokić, 2016: 227).

Može se postaviti pitanje, u vezi sa prihvaćenim rešenjem u srpskom pravu, da li je zakonom predviđeni rok od 27 godina, nakon kojeg osuđeni na doživotni zatvor stiče pravo da traži uslovni otpust (član 46 stav 2 alineja prva KZ),

39 Prema članu 184 stav 1 ZIKS direktor Uprave za izvršenje krivičnih sankcija može prevremeno otpustiti osuđenog sa izdržavanja kazne najviše šest meseci do isteka kazne, ako je izdržao devet desetina kazne, zbog dobrog vladanja osuđenog i postignutih rezultata u programu postupanja, na predlog upravnika zavoda; prema članu 184a stav 1 ZIKS sudija za izvršenje krivičnih sankcija može po predlogu upravnika zavoda prevremeno otpustiti osuđenog sa izdržavanja kazne zatvora najviše 12 meseci do isteka kazne, ako je osuđeni izdržao jednu polovinu kazne zatvora, zbog teške bolesti, teškog invaliditeta ili starosti, ako bi dalje izvršenje kazne predstavljalo nehumano postupanje (o ovom institutu više, Drakić, Milić, 2019b: 93-94). Jasno je iz navedenih odredaba da se radi o osuđenicima na „vremensku“ kaznu zatvora. 
kompatibilan sa standardima postavljenim u pomenutom predmetu Vinter $i$ drugi protiv Ujedinjenog Kraljevstva, jer se u ovoj odluci govori o postojanju „mehanizma za preispitivanje doživotnog zatvora nakon 25 godina“. Domaći autori koji su se bliže bavili ovom problematikom drže da u ovom slučaju nije odstupljeno od standarda ESLJP. Ovaj stav baziraju na tome da se ESLJP u svojim presudama „prvenstveno poziva na mogućnost preispitivanja nakon izricanja kazne doživotnog zatvora“", dok se u srpskom krivičnom pravu vreme provedeno u pritvoru, na izdržavanju mere zabrane napuštanja stana, kao i svako drugo lišenje slobode u vezi sa krivičnim delom uračunava u izrečenu kaznu zatvora, novčanu kaznu i rad u javnom interesu (član 63 stav $1 \mathrm{KZ}$ ). To znači da zakonski rok od 27 godina počinje da teče od dana lišenja slobode, dok se navedeni standard od 25 godina odnosi na period nakon izricanja kazne doživotnog zatvora (Turanjanin, 2021: 22). Navedeno tumačenje se dobrim delom oslanja i na argumentaciju iz predmeta Bodein protiv Francuske, predstavka broj 40014/10, koja je kasnije prihvaćena u predmetu Vella protiv Malte, predstavka br. 73182/12 (o tome, Turanjanin, 2021: 8-9). Naime, u prvonavedenom predmetu, raspravljalo se o roku od 30 godina koji propisuje francusko pravo za preispitivanje kazne doživotnog zatvora, s obzirom da je taj rok očigledno duži od standarda koji je određen na pomenutih na 25 godina. ESLJP je stao na stanovištu da podnosilac predstavke u tom slučaju nije lišen nade, kao i da je isti, uračunavanjem vremena provedenog u istražnom pritvoru, stekao pravo na preispitivanje kazne doživotnog zatvora nakon 26 godina od njegovog izricanja, što znači da bi teoretski ipak mogao biti pušten na uslovni otpust (Turanjanin, 2021: 9).

Ovo tumačenje se čini prihvatljivim, ali može biti sporno to što član 63 stav $1 \mathrm{KZ}$ reguliše uračunavanje vremena provedenog u pritvoru, na izdržavanju mere zabrane napuštanja stana kao i svakog drugog lišenja slobode u vezi sa krivičnim delom u izrečenu kaznu zatvora, novčanu kaznu i rad u javnom interesu, tako da ne spominje kaznu doživotnog zatvora. Otuda bi predmetna odredba morala biti novelirana, tako što bi se u njoj izričito naveo i doživotni zatvor, koji predstavlja posebnu kaznu u našem pravu. S druge strane, član 424 Zakonika o krivičnom postupku ${ }^{40}$ izričito predviđa da osuđujuća presuda sadrži i odluku o uračunavanju pritvora ili već izdržane kazne, tako da, s obzirom na situaciju nastalu uvođenjem doživotnog zatvora, odredbe materijalnog i procesnog prava u tom delu nisu saglasne.

40 Zakonik o krivičnom postupku, Službeni glasnik RS, br. 85/2005, 88/2005 - ispr., 107/2005 - ispr., 72/2009, 111/2009, 121/2012, 104/2013, 108/2014, 94/2016 i 35/2019. 


\section{Zaključna razmatranja}

Samo uvođenje doživotnog zatvora u sistem krivičnih sankcija Republike Srbije ne predstavlja ,problematično“ rešenje. Poznaje ga oko 85 \% država i posebnih teritorija u svetu (Radulović, 2020: 83). Po svojoj suštini i stepenu retributivnosti doživotni zatvor se ne razlikuje puno (ako se uopšte i razlikuje) od ranije postojećeg zatvora od 30 do 40 godina (više, Ćorović, 2018: 208-210). Moglo bi se reći da u odnosu na zatvor od 30 do 40 godina doživotni zatvor ima simbolički značaj, jer doprinosi da se umire ,preterana represivna nastojanja laičke javnosti, koja uporno zagovara prihvatanje što oštrijih mera u borbi protiv kriminaliteta“" (Đokić, 2016: 235).

Iz prethodnog izlaganja jasno je da se mogu uočiti dva značajnija sporna rešenja u vezi sa ovom kaznom. Prvo, da je doživotni zatvor propisan za odgovarajuće slučajeve krivičnih dela kvalifikovanih težom posledicom, gde smrt pasivnog subjekta, kao teža posledica, proizlazi iz nehatnog postupanja učinioca. Ovo rešenje je kriminalno-politički prilično sporno, na šta je već ukazivano u domaćoj literaturi, iako se slični primeri mogu naći i u uporednom pravu. Naravno, činjenica da slični slučajevi postoje u uporednom pravu, pa čak i kada je u pitanju nemačko krivično zakonodavstvo, koje nam je u mnogim slučajevima služilo kao uzor, nije dovoljan argument da se isto to (kod nas je čak i šire postavljeno) uvede i u krivično zakonodavstvo Republike Srbije.

Drugo, što je više problematično, jeste postojanje doživotnog zatvora bez uslovnog otpusta. Očigledno je da ova zakonska mogućnost nije kompatibilna sa praksom ESLJP, odnosno da predstavlja kršenje člana 3 Evropske konvencije, jer naše pravo ne poznaje neki drugi delotvorni mehanizam koji bi omogućio preispitivanje ove kazne nakon određenog vremenskog perioda. Okolnost da je doživotni zatvor bez uslovnog otpusta protivan članu 3 Evropske konvencije, ujedno znači da je protivan i članu 25 stav 2 Ustava Srbije. ${ }^{41}$ Nadalje, takvo rešenje je u koliziji i sa propisanom svrhom kažnjavanja iz člana $42 \mathrm{KZ}$, u delu u kojem se proklamuje specijalna prevencija (tačka 1 navedenog člana koja glasi: „sprečavanje učinioca da čini krivična dela i uticanje na njega da ubuduće ne čini krivična dela“), odnosno sa odredbom člana 43 ZIKS koja govori o svrsi izvršenja kazne zatvora (odredba glasi: „Svrha izvršenja kazne zatvora je da osuđeni tokom izvršenja kazne, primenom odgovarajućih programa postupanja, usvoji društveno prihvatljive vrednosti u cilju lakšeg uključivanja u uslove

41 Ustav Republike Srbije, Službeni glasnik RS, br. 98/2006. Navedena odredba glasi: „Niko ne može biti izložen mučenju, nečovečnom ili ponižavajućem postupanju ili kažnjavanju, niti podvrgnut medicinskim ili naučnim ogledima bez svog slobodno datog pristanka“. 
života posle izvršenja kazne kako ubuduće ne bi činio krivična dela“). Istina, potonji član ZIKS govori o svrsi izvršenja kazne zatvora, ne i doživotnog zatvora. Štaviše, ZIKS u svojim odredbama, isto kao i Zakon o izvršenju kazne zatvora za krivična dela organizovanog kriminala, ${ }^{42}$ uopšte ne pominje doživotni zatvor. Međutim, imajući u vidu da je reč o izvršnom propisu, da KZ ne određuje posebnu svrhu doživotnog zatvora, kao i da u najvećem broju slučajeva dopušta uslovni otpust kod ove kazne (što podrazumeva da se osuđeni tokom izdržavanja kazne popravio), trebalo bi uzeti da se odredba člana 43 ZIKS shodno primenjuje i na doživotni zatvor. U tom smislu može se konstatovati da se jedino u slučajevima kada je data mogućnost uslovnog otpusta, doživotni zatvor može upodobiti sa specijalnopreventivnim ciljevima kazne. Na ovaj način se doprinosi rešavanju problematike inkompatibiliteta doživotnog zatvora i rehabilitacione funkcije kazne (Manna, Infante, 2000: 41).

Ipak, problematiku zabrane uslovnog otpusta ne treba vezivati samo za doživotni zatvor. Kod doživotnog zatvora predmetna zabrana je „najupečatljivija“. Pri tome, ovde mislimo na apsolutnu zabranu uslovnog otpusta koja se vezuje za osudu za odgovarajuća krivična dela. Takva zabrana je i u slučaju vremenske kazne zatvora nespojiva sa navedenim specijalnopreventivnim učincima kazne. Njome se stavljaju van snage sve one odredbe materijalnog i izvršnog krivičnog prava koje govore o resocijalizaciji (rehabilitaciji ili reintegraciji) osuđenika, a dovodi se u pitanje i jednakost osuđenika pred zakonom. Prema tome, glavni problem u našem sistemu, a povodom problematike o kojoj govorimo, leži upravo u apsolutnoj zabrani uslovnog otpusta. Uklanjanjem ove zabrane rešili bi se brojni problemi o kojima je bilo reči .

Postojanje uslovnog otpusta kod doživotnog zatvora ne znači i to da će osuđeni obavezno biti pušten nakon izdržanih 27 godina. U ovom slučaju uslovni otpust je, prema članu 46 stav $2 \mathrm{KZ}$, fakultativan, tj. postoji diskreciono ovlašćenje suda da molbu osuđenika odbije ukoliko ne stekne uverenje da će se on na slobodi dobro vladati. Prema tome, osuđeni ima pravo da traži uslovni otpust, ali to ujedno ne znači da će ga i dobiti.

Do uvođenja doživotnog zatvora, u režimu fakultativnog uslovnog otpusta nalazio se zatvor od 30 do 40 godina. Nakon njegovog uvođenja (član 6 stav 1 Zakona o izmenama i dopunama KZ iz 2019.), osude na kaznu zatvora od 30 do 40 godina su ,automatski prešle“ iz režima fakultativnog u režim obaveznog uslovnog otpusta. To znači da ,će sud“ uslovno otpustiti sva lica koja su osuđena na zatvor od 30 do 40 godina ukoliko su ispunjeni uslovi iz člana 46 stav $1 \mathrm{KZ}$

42 Zakon o izvršenju kazne zatvora za krivična dela organizovanog kriminala, Službeni glasnik RS, br. $72 / 2009$ i 101/2010. 
(pod uslovom da podnesu molbu), odnosno u ovim slučajevima sud nema odgovarajuća diskreciona ovlašćenja kao u slučaju fakultativnog uslovnog otpusta iz člana 46 stav $2 \mathrm{KZ} .{ }^{43}$ Naravno, obavezni uslovni otpust (član 46 stav $1 \mathrm{KZ}$ ) ne znači da se isti ,odobrava po automatizmu, već nakon što sud utvrdi da je svaki pojedinačni osuđenik ostvario propisani napredak. Fokus je, dakle, na individualnom a ne na generalnom pristupu“ (Kolaković-Bojović, 2017: 147). Međutim, ipak je reč o režimu koji je povoljniji po osuđenike. Imajući u vidu da se osude na zatvor od 30 do 40 godina odnose na krivična dela za koja je sada propisan doživotni zatvor, pitanje je koliko je opravdano da te osude sada budu u blažem režimu uslovnog otpusta, tj. režimu iz člana 46 stav $1 \mathrm{KZ}$.

Na kraju, potrebno je reći da je povodom doživotnog zatvora ostalo da se urede brojna pitanja u materijalnom i izvršnom krivičnom zakonodavstvu. Pre svega, neophodno je urediti odnos između ove kazne i mera bezbednosti, te revidirati odredbu člana $63 \mathrm{KZ}$, tako što će se izričito propisati da se pritvor i svako drugo lišenje slobode povodom krivičnog dela uračunava i u izrečenu kaznu doživotnog zatvora. S druge strane, neprihvatljivo je da izvršna krivična legislative uopšte ne spominje doživotni zatvor. Imajući u vidu da je doživotni zatvor posebna kazna (za razliku od zatvora od 30 do 40 godina), bilo bi korisno da ona dobije posebno mesto u ZIKS, odnosno da se barem urede specifičnosti pravnog položaja osuđenika na ovu kaznu. ${ }^{44}$

\section{Literatura}

- CRIN (2015) Inhuman Sentencing: Life Imprisonment of Children around the World. Research Report. London: Child Rights International Network.

- Ćorović, E (2015) Sistem krivičnih sankcija Republike Srbije. Novi Pazar-Niš: Autorsko izdanje-SVEN.

43 U presudi Vrhovnog kasacionog suda, Kzz 587/2019 od 13.06.2019. godine, stoji: „Pri tome se posebno ukazuje da primena odredbe člana 5. KZ odnosno primena blažeg zakona na učinioca krivičnog dela je moguća samo do pravnosnažnog okončanja predmetnog krivičnog postupka, a prilikom odlučivanja o ispunjenosti uslova za uslovno otpuštanje primenjuju se odredbe zakona koji te uslove propisuje i važi u vreme izvršenja kazne odnosno donošenja odluke o uslovnom otpustu". (https://sudskapraksa.sud.rs/sudska-praksa, pristup 18.03.2021).

44 Za sve kazne iz našeg prava, osim doživotnog zatvora, predviđena su posebna pravila o njihovom izvršenju. Tako ZIKS reguliše izvršenje kazne zatvora (čl. 43-186), novčane kazne (čl. 187-193) i oduzimanja vozačke dozvole (član 194), dok je izvršenje rada u javnom interesu regulisano Zakonom o izvršenju vanzavodskih sankcija i mera (Službeni glasnik RS, br. 55/2014 i 87/2018; čl. 38-43). ZIKS takođe sadrži pravila o izvršenju mera bezbednosti (istina ne svih), ali i o izvršenju sankcija za prekršaj, kao i mere pritvora. Zanimljivo je da je izvršenju kazne zatvora za prekršaje posvećeno 17 članova (čl. 215-232), dok se doživotni zatvor uopšte ne spominje. 
- Ćorović, E. (2018) Kazna doživotnog zatvora (da ili ne). U: Bejatović S. (ur.) Organizacija pravosuđa i efikasnost sudske zaštite (Evropski standardi i stanje u Srbiji - krivičnopravni aspekt). LVIII redovno godišnje savetovanje Udruženja (Zlatibot, septembar 2018). Beograd: Srpsko udruženje za krivičnopravnu teoriju i praksu - Intermex, 194-210.

- Ćorović, E. (2020) Kritički osvrt na neke odredbe Krivičnog zakonika Srbije o odmeravanju i zabrani ublažavanja kazne. U: M. Simović (ur.), Krivično zakonodavstvo i prevencija kriminaliteta (norma i praksa). Jedanaesta međunarodna naučnostručna konferencija (Trebinje, 23-24. april 2020.). Laktaši-Beograd: Grafomarko-Srpsko udruženje za krivičnopravnu teoriju i praks, str. 159-176.

- Delić, N. (2009). Nova rešenja opštih instituta u KZS. Beograd: Pravni fakultet Univerziteta u Beogradu.

- Dragičević-Dičić, R (2015) U susret izmenama Krivičnog zakonika. Bilten Vrhovnog kasacionog suda, 2, str. 11-31.

- Drakić, D., Milić, I. (2019a) O pojedinim materijalnim, procesnim i izvršnim aspektima uslovnog otpusta. Zbornik radova Pravnog fakulteta u Novom Sadu, 2, str. 405-417. https://doi.org/10.5937/zrpfns53-23484

- Drakić, D., Milić, I. (2019b) Osnovi krivičnog izvršnog prava. Novi Sad: Pravni fakultet u Novom Sadu.

- Đokić, I. (2016) Reforma kazne zatvora u krivičnom zakonodavstvu Republike Srbije - kazna zatvora u dugom trajanju ili doživotni zatvor? U: Bejatović S. (ur.) Evropske integracije i kazneno zakonodavstvo (Poglavlje 23 - norma, praksa i mere harmonizacije). LVI redovno godišnje savetovanje Udruženja (Zlatibor, septembar, 2016). Beograd: Srpsko udruženje za krivičnopravnu teoriju i praksu - Intermex, str. 222-235.

- Ignjatović, Đ. (2016) Uslovni otpust - pravna i penološka analiza. Anali Pravnog fakulteta u Beogradu, 1, str. 31-66. https://doi.org/10.5937/AnaliPFB1601031I

- Ignjatović, Đ. (2019) Kazna doživotnog zatvora - razlozi uvođenja i osvrt na rešenja u poslednjoj noveli Krivičnog zakonika. U: S. Bejatović (ur.), Izmene u krivičnom zakonodavstvu $i$ status nosilaca pravosudnih funkcija $i$ adekvatnost državne reakcije na kriminalitet (Međunarodni pravni standardi i stanje u Srbiji). LIX redovno godišnje savetovanje Udruženja (Zlatibor, septembar, 2019). Beograd: Srpsko udruženje za krivičnopravnu teoriju i praksu - Intermex, str. 119-141.

- Ilić, G. (2019) Marginalije o kazni doživotnog zatvora, uslovnom otpustu i ljudskim pravima. U: Đ. Ignjatović (ur.), Kaznena reakcija u Srbiji - IX deo. Beograd: Pravni fakultet Univerziteta u Beogradu, str. 123-142.

- Ilić, V. (2019) (Ne)pomirljivost kazne doživotnog zatvora i ljudskih prava. Crimen, br. 2, str. 156-173. 
- Jovašević, D. (2017) Uslovni otpust u pravu Republike Srbije - teorija, praksa, uporedno zakonodavstvo. Zbornik radova Pravnog fakulteta u Nišu, 77, str. 53-74. https://doi.org/10.5937/zrpfni1777053J

- Kolaković-Bojović, M. (2017) Uslovni otpust i mere bezbednosti medicinskog karaktera. U: S. Bejatović, I. Ivanović (ur.), Mere bezbednosti medicinskog karaktera - pravni i medicinski aspekti (regionalna zakonodavstva, iskustva u primeni i mere unapređenja). Beograd: OEBS, 145-153.

- Kolarić, D. (2015) Doživotni zatvor - Pro et contra. Pravni život, 9, str. 641-657.

- Kolarić, D. (2019) Krivični zakonik i (ne)adekvatnost državne reakcije na kriminalitet (sadašnje stanje i nova rešenja). U: S. Bejatović (ur.), Izmene u krivičnom zakonodavstvu i status nosilaca pravosudnih funkcija i adekvatnost državne reakcije na kriminalitet (Međunarodni pravni standardi i stanje u Srbiji). LIX redovno godišnje savetovanje Udruženja (Zlatibor, septembar, 2019). Beograd: Srpsko udruženje za krivičnopravnu teoriju i praksu - Intermex, str. 22-41.

- Lackner, K., Kühl, K. (2011) StGB: Strafgesetzbuch - Kommentar. München: C.H. Beck.

- Manna, A., Infante, E. (2000) Criminal Justice Systems in Europe and North America: Italy. Helsinki: HEUNI.

- Miladinović-Stefanović, D. (2014) Krivičnopravna zaštita maloletnih lica od seksualnog iskorišćavanja i zlostavljanja - evropski standardi i pravo Republike Srbije. Zbornik radova Pravnog fakulteta u Nišu, 68, str. 567-584. https://doi. org/10.5937/zrpfni1468567M

- Milić, I. (2020) Novine u opštem delu Krivičnog zakonika. Zbornik radova Pravnog fakulteta u Novom Sadu, 1, str. 367-381. https://doi.org/10.5937/zrpfns54-23822

- Radulović, D. (2020) Dugotrajni ili doživotni zatvor. Revija za kriminologiju $i$ krivično pravo, 1-2, str. 69-87. https://doi.org/10.47152/rkkp.58.1.2.4

- Ristivojević, B. (2013) „Punitivni populizam“ srpskog zakonodavca - kritička analiza tzv. Marijinog zakona. U: Bejatović S. (ur.) Nova rešenja u kaznenom zakonodavstvu Srbije i njihova praktična primena. Pedeseto redovno godišnje savetovanje Udruženja (Zlatibor, septembar 2013). Beograd: Srpsko udruženje za krivičnopravnu teoriju i praksu - Intermex, 319-338.

- Stojanović, Z (2015) Sistem kazni u krivičnom pravu Srbije i potreba njegovog daljeg usavršavanja. U: Đ. Ignjatović (ur.), Kaznena reakcija u Srbiji-V deo. Beograd: Pravni fakultet Univerziteta u Beogradu, 1-24

- Stojanović, Z (2019) Komentar Krivičnog zakonika. Beograd: Službeni glasnik.

- Škulić, M. (2019) Krivična dela protiv polne slobode. Beograd: Službeni glasnik. 
- Turanjanin, V. (2021) Life Imprisonment Without Parole: The Compatibility of Serbia's Approach with the European Convention on Human Rights. Liverpool Law Rev, https://doi.org/10.1007/s10991-020-09269-6.

- Vuković, I. (2021) Krivično pravo: Opšti deo. Beograd: Pravni fakultet Univerziteta u Beogradu.

\section{Propisi}

- Ustav Republike Srbije, Službeni glasnik RS, br. 98/2006.

- Zakon o ratifikaciji Konvencije Ujedinjenih nacija o pravima deteta, Službeni list SFRJ - Međunarodni ugovori, br. 15/90, Službeni list SRJ - Međunarodni ugovori, br. 4/96 i 2/97.

- Zakon o ratifikaciji Evropske konvencije za zaštitu ljudskih prava i osnovnih sloboda, izmenjene u skladu sa Protokolom broj 11, Protokola uz Konvenciju za zaštitu ljudskih prava i osnovnih sloboda, Protokola broj 4 uz Konvenciju za zaštitu ljudskih prava i osnovnih sloboda kojim se obezbeđuju izvesna prava i slobode koji nisu uključeni u Konvenciju i Prvi Protokol uz nju, Protokola broj 6 uz Konvenciju za zaštitu ljudskih prava i osnovnih sloboda o ukidanju smrtne kazne, Protokola broj 7 uz Konvenciju za zaštitu ljudskih prava i osnovnih sloboda, Protokola broj 12 uz Konvenciju za zaštitu ljudskih prava i osnovnih sloboda i Protokola broj 13 uz Konvenciju za zaštitu ljudskih prava i osnovnih sloboda o ukidanju smrtne kazne u svim okolnostima, Službeni list SCG - Međunarodni ugovori, br. 9/2003, 5/2005 i 7/2005 - ispr.; Službeni glasnik RS - Međunarodni ugovori, br. 12/2010 i 10/2015.

- Krivični zakonik, Službeni glasnik RS, br. 85/2005, 88/2005 - ispr., 107/2005 - ispr., 72/2009, 111/2009, 121/2012, 104/2013, 108/2014, 94/2016 i 35/2019.

- Zakon o izmenama i dopunama Krivičnog zakonika, Službeni glasnik RS, br. 94/2016.

- Zakon o izmenama i dopunama Krivičnog zakonika, Službeni glasnik RS, br. $35 / 2019$.

- Zakon o izvršenju kazne zatvora za krivična dela organizovanog kriminala, Službeni glasnik RS, br. 72/2009 i 101/2010

- Zakon o izvršenju krivičnih sankcija, Službeni glasnik RS, br. 55/2014 i 35/2019.

- Zakon o izvršenju vanzavodskih sankcija i mera, Službeni glasnik RS, br. 55/2014 i $87 / 2018$.

- Zakon o posebnim merama za sprečavanje vršenja krivičnih dela prtiv polne slobode prema maloletnim licima, Službeni glasnik RS, br. 32/2013.

- Zakonik o krivičnom postupku, Službeni glasnik RS, br. 85/2005, 88/2005 - ispr., 107/2005 - ispr., 72/2009, 111/2009, 121/2012, 104/2013, 108/2014, 94/2016 i $35 / 2019$. 


\section{Presude}

- Laszlo Magyar v. Hungary, (Application no. 73593/10), https://hudoc.echr. coe.int/eng\#\{\%22itemid\%22:[\%22001-144109\%22]\}, stranici pristupljeno, 07.03.2021.

- Öclan v. Turkey, (Aplications nos. 24069/03, 197/04, 6201/06 and 10464/07). https://hudoc.echr.coe.int/eng\#\{\%22languageisocode $\% 22:[\% 22 \mathrm{ENG} \% 22]$,$\% 22$ appno\%22:[\%2224069/03\%22,\%22197/04\%22,\%226201 $106 \% 22, \% 2210464 / 07 \% 22$ ], \%22 documentcollectionid2\%22:[\%22CHAMBER\%22],\%22itemid\%22:[\%22001-142087\%22]\}, stranici pristupljeno 07.03.2021.

- Vinter and Others v. The United Kingdom, (Applications nos. 66069/09, 130/10 and 3896/10), https://hudoc.echr.coe.int/eng\#\{\%22itemid\%22: [\%22001-122664\%22]\}(07.03.2021.), stranici pristupljeno 07.03.2021.

- Presuda Vrhovnog kasacionog suda Kzz 587/2019 od 13.06.2019. godine, https://sudskapraksa.sud.rs/sudska-praksa, stranici pristupljeno 18.03.2021.

\section{Ostalo}

- Nacrt zakona o izmenama i dopunama Krivičnog zakonika iz 2015., https:// www.paragraf.rs/dnevne-vesti/080515/080515-vest13.html, strnici pristupljeno 19.03.2021.

- Predlog zakona o izmenama i dopunama Krivičnog zakonika iz 2016., http://www.parlament.gov.rs/upload/archive/files/lat/pdf/predlozi_zakona/2769-16\%20-Lat..pdf, stranici pristupljeno 19.03.2021.

- Predlog izmena Krivičnog zakonika Fondacije „Tijana Jurić“, http://www.parlament.gov.rs/upload/archive/files/cir/pdf/akta_procedura/2017/Predlog\%20 izmene\%20Krivicnog\%20zakonika\%2003052017.pdf, stranici pristupljeno 05.02.2021.).

- Predlog zakona o izmenama i dopunama Krivičnog zakonika iz 2019., https:// www.srbija.gov.rs/prikaz/358229, stranici pristupljeno 02.02.2021. 
Emir ĆOROVIĆ, PhD

Associate Professor

Department of Law Science, State University in Novi Pazar

\section{LIFE IMPRISONMENT AND PAROLE WITHIN THE CRIMINAL LAW OF SERBIA: CERTAIN ISSUES AND DILEMMAS}

Life imprisoment was introduced to Serbian Criminal legislation with the amendments of Criminal Code from 2019. These amendments replaced the former penalty of imprisonment from 30 to 40 years. Special attention was drawn by the fact that the new legislation allows the possibility of life imprisonment without the possibility of parole for committing certain crimes. This legal solution is considered not to be in accordance with the Article 3 of the European Convention for for the Protection of Human Rights and Fundamental Freedoms. Still, the prohibiton of parole was introduced to Serbian criminal law in 2013, with the adoption of the Law on the special measures for the prevention of crimes against sexual freedom towards minors. However, at that time the academic community did not give the attention it deserved to the justification of this prohibition, which by itself generates many concerns. That is why, when discussing the problematics of life imprisonment and parole, and its prohibition, one has to bear in mind the previously structured legal frame, as well as the concerns that such a prohibition creates, regardless of whether it not it relates to life imprisoment or timely limited imprisonment.

Key words: life imprisonment, parole, prohibiton of parole. 